\title{
Problems Faced By Education and Educators during the Coronavirus Disease (Covid-19) Process
}

\author{
Erdal Bal ${ }^{*}$, Nedim Malkoç \\ Department of Exercise and Sport Sciences, University of Health \\ Science, Istanbul, Ankara, Turkey \\ Study Area:Ankara, Turkey \\ Coordinates: $40.98716^{\circ} \mathrm{N} ; 29.05434^{\circ} \mathrm{E}$
}

Key words: Covid-19, Mental Health, Learning

Technology, E-learning, Pandemic Year

\section{Introduction:}

The terrible Novel, Corona Virus disease, emerged in 2019 towards the end of December at a seafood market in Wuhan city, south of China (Huang et al., 2020). Covid-19, which presents itself in the human body with flu-like symptoms acutely similar to those of pneumonia, was discovered in the Chinese Center for Disease Control and prevention at a virology laboratory (The State Council of The People's Republic of China, 2020). Since its discovery, the amount of people who are infected has increased tremendously, breaking past the walls of china into the rest of the world, with millions of people now infected globally and thousands of causalities (Sina News, 2020). The coronavirus epidemic was declared a pandemic by the world health organization, and measures have been put in place to stop its rapid spread (WHO, 2020). Enforcing lockdowns, among other preventive measures in almost all the countries worldwide, is unavoidable since it helps curb the spread of this highly infectious disease. Schools have closed all around the world, shutting down all learning activities (UNESCO, 2020), and families are going into quarantine to stay safe and avoid contracting COVID-19 due to exposure and staying in crowded places without knowing who is infected. As our leaders with the help of their advisors and

\section{Abstract}

Because of the increasing worry about the ongoing COVID19 epidemic, many educational institutes all over the world have shut down their day-to-day activities to regulate the infection rate and keep students safe. The coronavirus disease has brought about worry and concern on people. This disease is both a big challenge and a learning opportunity for the world's education system. These problems caused many scientists from educational sciences to sports sciences, from health sciences to social sciences to focus on the subject. Qualitative research methods used in this research paper to analyze data Technology has been adapted into the education system to facilitate the continuation of studying through online platforms such as eLearning. No one had anticipated this disease, and this has resulted in a lot of chaos in the education system due $t$ unpreparedness and lack of sufficient ways to cope. Some students have been able to continue with their studies while others have not been lucky. Parents are now the new teacher's online learning platforms in the new classrooms.

medical personnel experienced in the fight of infectious diseases are trying their best to fight the pandemic, learning institutions are equally attempting to find ways to continue with the studying and teaching process for all the students and the educators.

Many activities have hit pause due to this COVID-19 health crisis, especially in the education sector (Bedford et al., 2020). In an attempt to regain normalcy and continue with the learning process, many institutions have shifted to the digital way of doing things. Technology has come in handy to supplement the lack of classrooms and the face to face process of teaching (Luca et al., 2018). Schools have shifted their curriculums online and are adopting new methods of studying through digital platforms. Academics, teachers, and schools are trying to adapt to this new norm in the best way they can since this pandemic has given them the opportunity to reflect on the teaching methods that are slowing losing their use at this time (Raaheim et al., 2019). Digital platforms are going to have a major impact on the education system for the next generations since information is now easily accessible through the internet.

The work of classrooms, teachers, and professors is slowly losing its value and meaning, and they have to find a way of incorporating themselves into the new way of life or

*Corresponding Author: emre.belli@atauni.edu.tr 
else erode away with the new way of things.

In this paper, the effects of the coronavirus on the education system are clearly outlined more so the challenges faced by students and teachers. There are quite a few challenges in the education sector as people are trying to adopt a new way of studying that was not fully in place before this pandemic, and this has equally brought about new problems such us; teachers losing their jobs, mental issues and quite a number of economic difficulties (Gewin, 2020). However, this is not the case for each individual due to different family backgrounds and different financial statuses. The universe at large is equipped with facilities and materials to sustain people in such situations, yet there is difficulty in the distribution and allocation of these resources to the people who need them.

The transition to online learning has been smooth for some institutions and individuals, yet others barely have a footing on how to transition into this digital era. Equally, in different homesteads, some families have had no trouble with adapting quickly and transitioning smoothly due to the availability of resources while others have not been as fortunate. This has resulted in a number of psychological issues because how the guardians face these challenges directly affects the offsprings and has a long-lasting effect on the kids' futures. Parents are now the new teachers, and the role of education has shifted into evaluating the impact of the new way of learning for future generations.

\section{Challenges faced by the academics and teachers:}

In an effort to keep up with the rest of the world during the COVID-19 pandemic, the education sector has put in place measures to help continue with the school's curriculums. However, the transition to digital learning has not been smooth, and this has resulted in some problems on both the learners, teachers, and the faculties as explained below:

The transition from a class to digital learning: the use of informational technology instead of face-to-face teaching seems to be quite an uphill task. Students and teachers who are used to the classroom scenario need to adapt to new ways of learning to achieve the standards education required (Remuzzi et al., 2020). Those students who are less fortunate in life and do not have easy access to the internet face the challenge of being left behind while the rest continue with their studies. This lead to an increased gap between the students since, in school, they are at the same levels, but at home, some luxuries are not common to all (Bedford et al., 2020). Furthermore, not all the students and teachers are techno-savvy, and some of the IT equipment is not easily affordable to hence widening the gap between students from different family backgrounds.

Evaluation and assessment: there are different subjects covered by the curriculum, and most of them taught easily through online platforms but not all, for example, the subjects that require practical's, art and music courses. This poses a challenge in the evaluation of a student since they require face-to-face time. Moreso, examinations and continuous assessment tests cannot be administered online due to irregularities that are prone to occur like cheating thus living the learning institutions with a challenge (Alruwais et al., 2018).

Economic problems: the COVID-19 pandemic has greatly affected the economy, especially in the educational sector. A great number of teachers have lost their jobs due to schools not being in session (Kearns, 2020). Furthermore, businesses that were running in schools due to student consumption like food outlets, shopping centres, and entertainment joints have shut down, and this has dealt a great blow to the economic growth and left many people unemployed. This has caused the economy of most learning institutions to plummet, creating a ripple effect on the world's economy as well.

Psychological problems: people's normal way of life was disrupted due to the coronavirus outbreak. The infection rate keeps rising day in, day out, and this has brought about mental distress to many people; students, teachers, and staff included (Xiang et al., 2020). The fear of not knowing what might happen today has greatly raised anxiety levels, especially in students, and thus hindering their education process (Thomas et al., 2020). Mental endurance of individuals is of great importance in such processes (Yasar \& Turgut, 2020). In addition, due to the hard economic times, some parents have lost their livelihood, and the lack of necessities has to lead to an increase in depression and stress. International students are the most affected since, on top of being worried about their own health and safety, they are in foreign counties and cannot travel back home, and the safety and welfare of their families are unknown to them. Hence, a few students and teachers are unable to go with studying and teaching because of the increased psychological issues.

Lack of jobs: Covid-19 struck the world severely when most students were about to do their examinations. This has hindered those undergraduates who were about to finish their courses on campus from finding jobs, and they have had to pause their lives due to the lack of certificates and qualifications that are essential in job hunting (Timmis et al., 2016). In addition, the number of teachers who got retrenched has a hard time finding work since their areas of expertise is education and schools are closed. Thus, jobs are hard to come by for most of the people in the educational sector (WHO, 2020).

\section{Solutions:}

Creating mental health awareness: with the infection rates of the coronavirus increasing rapidly, lockdowns have been put in place, and curfews have been implemented to keep people safe and at home (Wheeler et al., 2010). 
Students, teachers, and parents are all at home, and most of them undergoing depression and anxiety and are in need of psychological assistance. Educational institutes should find a way of creating mental health awareness to get to all the people in need of help in their homes without jeopardizing their safety. They should also upgrade their services such as counseling, online guidance, and help numbers should be availed to all the people (Tsinghua University, 2020). The international students should be given more care and provide them with essentials they might require during these hard times. The students who come from humble backgrounds should also be helped in some way so that the rest of the students do not leave them far behind. Psychological assistance during this crisis will go a long way in ensuring that most people find a way of dealing with issues that will arise during this pandemic. Educational sector support systems: this pandemic has brought about digital online studying. Learning institutes should put together a group of people, including members from various departments and students from different levels of learning who can evaluate the new way of learning while combating COVID-19 (Kawano et al., 2015). Students should be encouraged to participate in online learning through interactions with their teachers and fellow students as well to keep the learning process going. In addition, studying materials should be readily available for the students on the online learning platforms to make the transitions easier. In conclusion, when students and teachers work closely together in making sure that classes go on through online platforms, it will motivate more to do so, and the learning process will pick up again without hitches (Gewin, 2020).

Diversif $y$ studying through informational technology: students in higher institutes of learning can be outsourced to help in community awareness on the danger that the world is facing due to the pandemic (Wang et al., 2019). Different subjects require different ways of learning. Students can help the teachers understand how to use online platforms better to polish on the quality of education delivered to the other students. The courses that require face-to-face time with the teachers need to be postponed until the school reopens hopefully after a vaccine is found. Students should be encouraged to venture out into businesses or partake in more online courses to help those who have graduated and have no work or the students who were in there final year of school (Luo et al., 2020). By venturing out and finding something constructive to do, the students help in the recovery of the economies and in opening up their minds to more opportunities that life has to offer.

\section{Conclusion:}

The role of education in our lives is unprecedented. Education is an essential need, and it is through learning that people get to expand their mindsets, learn new ways of handling different situations and emergencies, and above all, learn how to solve problems and challenges they face. If there was a time that people needed education, it is now, to help combat the novel Corona Virus pandemic that the world is facing. People should be able to cope with the situations they face and adjust accordingly. The teaching and learning process has shifted from face to face to online studying; the teachers, students, and all learning institutions at large should be able to adapt accordingly. Of course, this is not easy for applied sciences. For example, online education applications in a field such as philosophy in schools are not strange, but new solutions will be required in areas such as sports sciences, health sciences and engineering. The online learning platforms have to suffice for now until the moment that there is a vaccine for COVID-19.

\section{References and Further Readings:}

Alruwais, N., Wills, G. \& Wald, M. (2018): Advantages and challenges of using eAssessment . Int. J. Inf. Edu. Technol., 8:34-37.

Bedford, J., Enria, D., Giesecke, J., Heymann, D.L., Ihekweazu, C.,Kobinger, G., Lane, H.C., Memish, Z., Oh, M-d., Sall, A.A., Schuchat, A., Ungchusak, K. \& Wieler, L.H., (2020): COVID19: towards controlling of a pandemic. Lancet., 10.1016/So1406736(20)30673-5

Gewin, V. (2020): Five tips for moving teaching online as COVID19 takes hold. Nature. 10.1038/d41586-020-00896-7

Kawano, S. \& Kakehashi, M. (2015): Substantial Impact of School Closure on the Transmission Dynamics during the Pandemic Flu H1N1-2009 in Oita, Japan. PLoS ONE, 10(12): eo144839

Kearns, L.R. (2012): Student assessment in online learning: challenges and effective practices. MERLOT J. Online Learn. Teach., 8(3):198-208.

Luca, G.D., Kerckhove, K.V., Coletti, P., Poletto, C., Bossuyt, N., Hens, N. \& Colizza, V. (2018): The impact of regular school closure on seasonal influenza epidemics: a data-driven spatial transmission model for Belgium. BMC Infect Dis., 18:29. 10.1186/s12879-017-2934-3

Luo, Y-M., Liu, W., Yue, X-G. \& Rosen, M.A. (2020): Sustainable Emergency Management Based on Intelligent Information Processing. Sustainability, 12(3):10.339o/su12031081.

Raaheim, A., Mathiassen, K., Moen, V., Lona, I., Gynnild, V., Bunæs, B.R. \& Hasle, E.T. (2019): Digital assessment - how does it challenge local practices and national law? A Norwegian case study. Eur. J. High Edu., 9:219-231. 10.108o/21568235.2018.1541420

Remuzzi, A. \& Remuzzi, G. (2020): COVID-19 and Italy: what next? Lancet., 10.1016/So140-6736(20)30627-9

Timmis, S., Broadfoot, P., Sutherland, R. \& Oldfield, A. (2016): Rethinking assessment in a digital age: opportunities, challenges and risks. Br. Edu. Res. J., 42:454-476.

Watson, G. \& Sottile, J. (2010): Cheating in the digital age: do students cheat more in online courses? Online J. Dist. Learn. Admin., 13(1). 


\section{Relevant URL:}

APA [American Psychological Association] (2020): Human behavior in the time of COVID-19: Learning from psychological science.

https://www.psychologicalscience.org/observer/humanbehavior-in-thetime-of-covid $\% 20-19$

As coronavirus spreads, the decision to move classes online is the first step. What comes next? (2020).

https://www.chronicle.com/article/AsCoronavirusSpreadsthe $/ 248200$

Coronavirus COVID-19 - latest update on Kingston University's r es ponse. ( 2020 ) :

https://www.kingston.ac.uk/news/article/2306/19-aug2020-coronavirus-covid19-latest-update-on-kingstonuniversitys-response/

Coronavirus: universities are shifting classes online - but it's not as easyasits o u nds. ( 2020 ) :https://theconversation.com/coronavirus-universities-areshifting-classes-online-but-its-not-as-easy-as-it-sounds133030
Sina News. (2020): A Total of 68,500 Newly Diagnosed Cases of New Coronary Pneumonia Nationwide. Available online: http://news.sina.com.cn/o/2020-02-16/dociimxxstf1795268.shtml

THE. Educating despite the COVID-19 outbreak: lessons from Singapore . (2020).

https://www.timeshighereducation.com/blog/educatingde spite-covid-19outbreak-lessons-singapore

Tsinghua University. 2020. Department of Psychology, Tsinghua University in action: "Combating Epidemics, Psychological Assistance” Emergency Public Welfare Project to Help Fight Ep i d e mi c.

http://news.tsinghua.edu.cn/publish/thunews/10303/2020/ 20200202095132036222403/20200202095132036222403_ht $\mathrm{ml}$

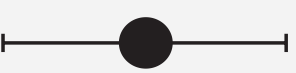

